\title{
PELATIHAN INTERNET MARKETING PADA SISWA SMK MUHAMMADIYAH 2 YOGYAKARTA
}

\author{
INTERNET MARKETING TRAINING FOR STUDENTS OF \\ VOCATIONAL HIGH SCHOOL MUHAMMADIYAH 2 YOGYAKARTA
}

\author{
Oleh: \\ Tikaridha Hardiani, Esi Putri Silmina, Sri Lestari Linawati \\ Program Studi Teknologi Informasi dan Pusat Pengembangan Bahasa \\ Universitas 'Aisyiyah Yogyakarta \\ Email: tikaridha@unisayogya.ac.id, esiputrisilmina@unisayogya.ac.id, \\ srilinawati@unisayogya.ac.id
}

\begin{abstract}
Muhammadiyah 2 Yogyakarta Vocational School is located at Jl. Tukangan No.1, Tegal Panggung, Danurejan, Yogyakarta City, Special Region of Yogyakarta 55212. Muhammadiyah 2 Vocational School Yogyakarta has 3 departments. Department of network and computer engineering, accounting, and office administration. At present there are 325 students of Muhammadiyah Vocational High School 2 Yogyakarta. The latest curriculum used by Muhammadiyah 2 Yogyakarta Vocational School is the 2017 curriculum. Using this curriculum it is expected that students have creativity and entrepreneurial product expertise competencies. In order to achieve these competencies students of class X SMK obtain digital simulation and communication subjects. In this lesson students learn communication in online networks, online communication applications, virtual classes, virtual classroom learning, video presentations, video presentations for branding and marketing, visual simulations, preproduction stage visual simulation processing applications, visual stage simulation processing applications production, stage visual simulation processing applications, postproduction, digital books, digital book formats, and digital book publications. Therefore, to support students having these competencies, internet marketing or online marketing is needed. Muhammadiyah 2 Yogyakarta Vocational School has a business charity to support students' abilities in the form of computer and laptop services. The computer and laptop service services are located next to Muhammadiyah 2 Vocational School in Yogyakarta. The results of these computer and laptop service services have not been maximized due to lack of marketing (marketing). Students of Muhammadiyah 2 Yogyakarta Vocational School after graduating in large part did not continue to the undergraduate level, they chose to work immediately. But the Regional Minimum Wage for vocational school graduates is relatively low, therefore they need additional income by entrepreneurship. The existence of these problems, the authors provide solutions with internet marketing training to support the competence of the students' expertise. This training is also useful for students of Muhammadiyah 2 Yogyakarta Vocational School to supplement their income by entrepreneurship using the use of internet marketing as a promotional media.
\end{abstract}

Keywords: internet marketing, promotion, entrepreneurship, marketing, online 


\section{PENDAHULUAN}

SMK Muhammadiyah 2 Yogyakarta merupakan salah satu SMK Muhammadiyah yang unggul di Yogyakarta. SMK Muhammadiyah 2 Yogyakarta berdiri sejak tanggal 2 Agustus 1965. Sekolah ini mulanya bernama SMEP Muhammadiyah 1 yang kemudian ditingkatkan statusnya menjadi SMEA Muhammadiyah 1 dengan program 4 tahun yang berkedudukan di J1. Kapas No.1 Yogyakarta (Tama, 2015). SMK Muhammadiyah 2 Yogyakarta sudah cukup terkenal di masyarakat, selain kualitasnya yang bagus, SMK Muhammadiyah 2 Yogyakarta sudah terbukti mencetak lulusan yang berprestasi dan mempunyai sikap bersaing. Sebagai sekolah yang telah diakui kini SMK Muhammadiyah 2 Yogyakarta telah terakreditasi A (http://smkmuh2-yog.sch.id/v2/). Sekolah yang berada di Kota Yogyakarta ini merupakan sekolah dengan potensi yang cukup bagus. Sekolah ini berstatus sebagai sekolah swasta di bawah yayasan organisasi Islam Muhammadiyah dan dilihat dari letaknya cukup kondusif untuk melakukan kegiatan belajar mengajar. Siswa/siswi SMK Muhammadiyah 2 Yogyakarta juga ikut andil dalam berbagai perlombaan. Hal ini membuktikan bahwa SMK Muhammadiyah 2 Yogyakarta selain berprestasi dalam bidang akademik juga berprestasi dalam mengembangkan potensi siswa dalam bidang non-akademik.

Kurikulum terbaru SMK mengacu pada kurikulum 2017, dengan kurikulum ini diharapkan siswa memiliki kompetensi keahlian produk kreatifitas dan kewirausahaan. Guna memenuhi kompetensi tersebut, siswa/siswi SMK kelas X (sepuluh) memperoleh mata pelajaran simulasi dan komunikasi digital. Pada pelajaran ini siswa mempelajari komunikasi dalam Jaringan Daring (Online), penerapan komunikasi daring, kelas maya, pembelajaran melalui kelas maya, presentasi video, presentasi video untuk branding dan marketing, simulasi visual, aplikasi pengolah simulasi visual tahap praproduksi, aplikasi pengolah simulasi visual tahap produksi, aplikasi pengolah simulasi visual tahap, pascaproduksi, buku digital, format buku digital dan publikasi buku digital. Untuk mendukung siswa memiliki kompetensi tersebut, dibutuhkan ilmu internet marketing atau pemasaran online. Data alumni SMK Muhammadiyah 2 Yogyakarta diperoleh lebih dari $50 \%$ siswa memilih untuk bekerja, 10\% siswa melanjutkan ke Perguruan Tinggi dan sisanya berwirausaha. Sebagian besar siswa bekerja di toko, mall dan bengkel.

SMK Muhammadiyah 2 Yogyakarta mempunyai amal usaha untuk mendukung kemampuan siswa, yaitu jasa service komputer dan laptop. Jasa service komputer dan laptop tersebut terletak di samping SMK Muhammadiyah 2 Yogyakarta. Hasil dari jasa service komputer dan laptop tersebut belum maksimal dikarenakan kurangnya pemasaran atau marketing. Pemasaran atau marketing salah satu perangkat vital dalam suatu bisnis, sistem pemasaran yang baik merupakan pendukung siklus hidup sebuah produk (product lifecycle) (Muttaqin, 2011). Pemasaran online adalah segala sesuatu yang dilakukan untuk melakukan pemasaran suatu produk atau jasa melalui internet. Di zaman teknologi informasi saat ini pemanfaatan media sosial dalam pemasaran online lebih efektif dan efisien. Media sosial online merupakan media yang didesain untuk memudahkan interaksi sosial bersifat interaktif dengan berbasis teknologi internet yang mengubah pola penyebaran informasi dari sebelumnya bersifat broadcast media monologue (satu ke banyak audiens) ke social media dialogue (banyak audiens ke banyak audiens) (Utami, 2012). Facebook dan instagram marketing memudahkan penjual dengan menentukan pembeli yang tertarget. Facebook merupakan web ketiga yang paling banyak dikunjungi orang. Peringkat pertama adalah google dan peringkat kedua adalah youtube (Handayani, 2016). Facebook menciptakan peluang bagi organisasi untuk berkomunikasi secara langsung, cepat, dan konsisten dengan jutaan pelanggan. Selain itu, munculnya Facebook 
sebagai platform pemasaran telah mengantarkan area baru dari periklanan yang dipersonalisasi dan lebih tertarget (Ramsaran, 2013). Survey yang dilakukan Nielson Indonesia di Jakarta, Bodetabek, Bandung, Surabaya, Jogja, Semarang, Medan, Makasar dan Denpasar, menunjukkan bahwa facebook sebagai media sosial yang dominan di seluruh Asia Tenggara. Hasil survey tersebut menghasilkan 90\% dari konsumen digital di Indonesia memiliki profil aktif di facebook (Ekawati, 2012). Data tersebut menunjukkan facebook sangat berpotensi untuk pemasaran online.

Facebook marketing adalah melakukan aktivitas marketing menggunakan semua fasilitas yang disediakan oleh facebook dengan tujuan meningkatkan penjualan (sales) dan menjalin komunikasi yang lebih langgeng dengan pelanggan (customer relationship) (Muttaqin, 2011).

Tujuan facebook marketing adalah sebagai berikut (Muttaqin, 2011 ):

a. Communitization

Pembentukan komunitas yang terdiri dari orang-orang yang memiliki kepentingan dan ketertarikan yang sama yang terkait dengan produk anda.

b. Clarification

Membentuk persepsi tentang siapa dan apa produk kita di benak konsumen. Disamping itu dalam Clarification kita harus mampu menjawab dan memperjelas jika ada konsumen yang masih bingung atau memiliki persepsi yang berbeda tentang siapa dan apa produk kita.

c. Commercialization

Terjadinya penjualan kemudian membangun hubungan yang berkelanjutan.

d. Connection

Menjaga hubungan agar selalu dekat dengan pelanggan, melalui kedekatan ini dapat tercipta penjualan yang berkelanjutan.

e. Characterization

Meningkatkan brand awareness atau kesadaran terhadap merk, sehingga konsumen dapat dengan mudah mengingat, mengenali dan membedakan dengan jelas produk kita dengan produk yang lain.

f. Conversation

Membicarakan atau menyebarkan informasi kepada komunitas tentang apa yang kita lakukan, sehingga konsumen turut serta mempromosikan produk kita kepada konsumen lainnya.

g. Combination

Gabungan dua atau lebih tujuan dari Facebook marketing

Adapun tujuan kegiatan pengabdian masyarakat ini adalah:

1. Mendukung mata pelajaran simulasi dan komunikasi digital pada kelas X.

2. Memberikan pengetahuan pemasaran online untuk siswa sebagai bekal dalam mencari pekerjaan dan berwirausaha.

Diharapkan kegiatan Pengabdian Masyarakat ini dapat memberikan manfaat, antara lain:

1. Manfaat bagi siswa

Siswa memiliki pengetahuan pemasaran online untuk siswa sebagai bekal dalam mencari pekerjaan dan berwirausaha

2. Manfaat bagi tim pelaksana

Pengalaman ini diharapkan dapat memberikan pengalaman berinteraksi langsung dengan siswa SMK sehingga mampu merumuskan solusi yang lebih baik untuk 
membantu siswa dalam bekal berwirausaha dan membantu mendukung berjalannya mata pelajaran simulasi digital.

3. Manfaat bagi institusi

Melalui kegiatan ini diharapkan dapat terjalin kerjasama lebih baik antara Universitas 'Aisyiyah Yogyakarta dan SMK Muhammadiyah 2 Yogyakarta, sehingga dapat memberikan kontribusi positif pada kedua pihak.

\section{METODE PENGABDIAN}

Metode yang digunakan dalam pengabdian masyarakat ini yaitu pelatihan internet marketing yang berupa menyampaikan materi dan diskusi tentang pemasaran di internet atau pemasaran online. serta praktik internet marketing. Praktik internet marketing berupa melakukan pemasaran online dengan memaksimalkan media sosial. Di akhir pertemuan, dilakukan evaluasi terhadap pelatihan yang dilakukan. Evaluasi tersebut berupa penyampaian pesan dan kesan oleh para siswa dan rencana bisnis yang ingin dikembangkan dengan memperhatikan target pasar menggunakan optimalisasi media sosial. Pengabdian masyarakat ini dilaksanakan selama 3 hari, pada tanggal 6 Februari, 8 Februari dan 9 Februari 2018. Kegiatan pengabdian masyarakt diikuti siswa kelas X yang terdiri dari 5 kelas yaitu 2 kelas Teknik Jaringan Komputer, 2 kelas jurusan Akuntansi dan 1 kelas jurusan Administrasi Perkantoran. Pelatihan internet marketing dilaksanakan di laboratorium komputer dan ruang kelas SMK Muhammadiyah 2 Yogyakarta. Total waktu yang digunakan 2 jam pelajaran yaitu 2x45 menit.

\section{HASIL DAN PEMBAHASAN}

Kegiatan pengabdian masyarakat pelatihan internet marketing terdiri dari beberapa kegiatan. Kegiatan awal merupakan perkenalan tim pelaksana dan pengenalan awal tentang berdagang dalam pandangan Islam serta kehidupan berbisnis dalam Islam. Materi ini diambilkan dari PHIWM (Pedoman Hidup Islami Warga Muhammadiyah) tentang kehidupan dalam berbisnis. Kegiatan selanjutnya penyampaian materi tentang internet marketing, optimasisasi media sosial khususnya penggunaan facebook. Dengan penggunaan facebook yang optimal kita dapat memasarkan produk sesuai dengan target pasar yang diinginkan. Penggunaan tools intelligence search di chrome mempermudah pemilihan friends sesuai kriteria yang diinginkan. Setelah menerima materi, para siswa mempraktikkan di akun facebook masing-masing. Sebelum mengakhiri pertemuan, para siswa diminta menyampaikan kesan dan pesan tentang pelatihan yang diberikan serta siswa diminta menuliskan rencana berwirausaha sesuai target pasar yang diinginkan. Pertanyaan yang diberikan pada siswa yaitu:
a. Bisnis apa yang akan Anda jalankan?
b. Siapa target pasar Anda?
c. Dimana lokasi yang dijadikan target jual?
d. Usia berapa yang akan membeli produk Anda?
e. Gender pembeli produk Anda? 
Tabel 1. Rincian Kegiatan Pengabdian Masyarakat

\begin{tabular}{cl}
\hline Nama Kegiatan & \multicolumn{1}{c}{ Rincian Pelaksanaan } \\
\hline Kegiatan awal & Pengenalan awal tentang berdagang dalam Islam oleh Sri \\
& Lestari Linawati, S.S., M.S.I. \\
Kegiatan inti & $\begin{array}{l}\text { Penyampaian materi tentang internet marketing dan praktik } \\
\text { dipandu oleh Tikaridha Hardiani S.Kom., M. Eng }\end{array}$ \\
Kegiatan akhir & Umpan balik dan evaluasi \\
\hline
\end{tabular}
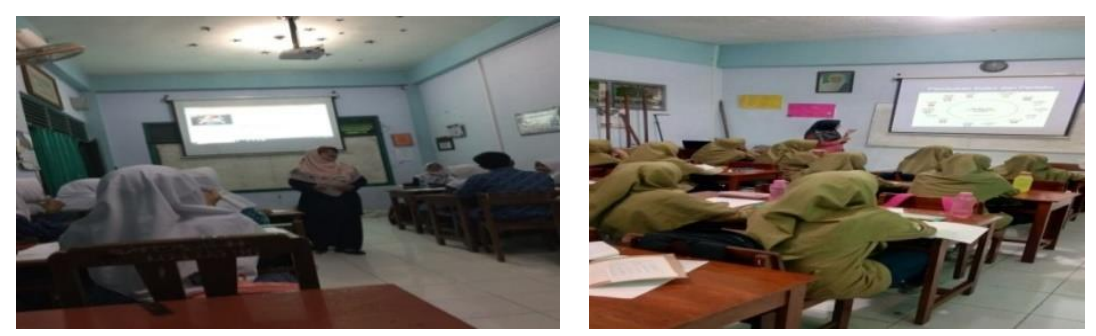

Gambar 1. (a). Penyampaian materi awal, (b). Penyampaian materi internet marketing
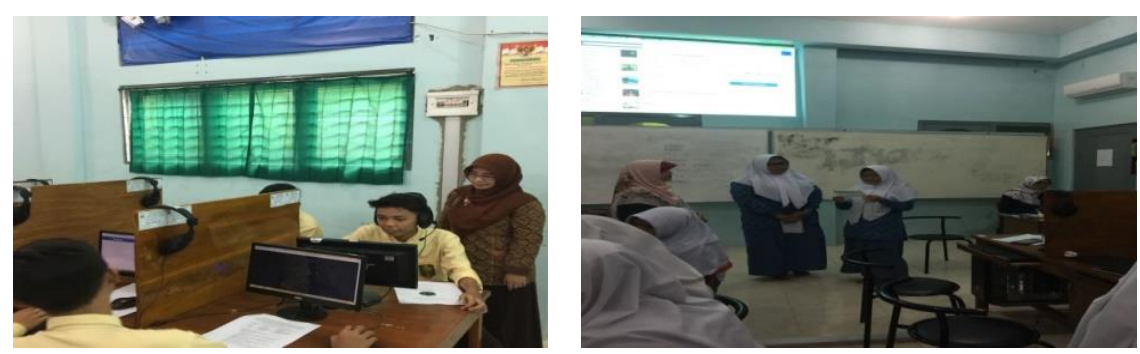

Gambar 2. (a). Siswa mempraktikkan materi yang disampaikan, (b). Siswa menyampaikan kesan dan pesan serta evaluasi

Pengabdian masyarakat di SMK Muhammadiyah 2 Yogyakarta dilakukan selama 3 hari. Pada tanggal 6 Februari, 8 Februari dan 9 Februari 2018. Siswa yang mengikuti pelatihan siswa kelas $\mathrm{X}$ semua jurusan yang terdiri dari 5 kelas. Pelatihan internet marketing ini berjalan dengan lancar walaupun koneksi wifi tidak lancar. Beberapa kesan dan pesan yang diberikan oleh siswa yaitu sebagai berikut:

1. Alhamdulillah bisa mengerti tentang internet marketing dan bisa menambah pengetahuan saya, dan jadi ingin berjualan jaket, sepatu, dll. Saya senang sekali hari ini. (Gilang Ramadhani)

2. Pengalaman menarik pembelajaran pagi ini adalah mendapatkan motivasi baru untuk berniaga secara online. Mendapatkan dasar-dasar atau cara-cara yang tepat untuk jual beli online. Bisa tahu barang apa saja yang laku di pasaran. Termotivasi untuk melakukan jual beli online seperti jaket, topi, kaos dan motor. (Faiq)

3. Pengalaman yang saya dapat pada pagi hari ini: cara memasarkan produk secara online, mengetahui dasar-dasar ilmu online marketing dan mendapat wifi gratis. (Dimas Rizki) 


\section{KESIMPULAN DAN SARAN}

\section{Kesimpulan}

Kesimpulan yang dapat ditarik setelah melakukan pengabdian masyarakat yang berjudul Pelatihan Internet Marketing pada Siswa SMK Muhammadiyah 2 Yogyakarta adalah:

1. Kegiatan pengabdian masyarakat berupa pelatihan internet marketing dilakukan untuk mendukung kegiatan belajar mengajar mata pelajaran simulasi digital yang ada pada kurikulum SMK Muhammadiyah 2 Yogyakarta dan memberikan motivasi berwirausaha serta memanfaatkan internet marketing sebagai sarana berwirausaha.

2. Siswa/siswi yang mengikuti kegiatan pelatihan internet marketing ada 3 jurusan, yaitu: 2 kelas Teknik Jaringan Komputer, 2 kelas Jurusan Akuntansi dan 1 kelas Jurusan Administrasi Perkantoran.

3. Kegiatan pelatihan internet marketing dilaksanakan sebanyak 5 kali dengan dibagi menjadi 3 hari, yaitu pada Hari Selasa tanggal 6 Februari 2018, Kamis tanggal 8 Februari 2018, dan Jumat tanggal 9 Februari 2018.

\section{Saran} lain:

Saran yang dapat jadi masukan dalam pelaksanaan kegiatan pengabdian ini antara

1. Perlu adanya pelatihan lanjutan bagi siswa/siswi yang berminat berwirausaha, khususnya menggunakan internet marketing.

2. Memberikan pengantar materi yang mengarahkan ke siswa untuk lebih fokus mengikuti pelatihan internet marketing.

\section{DAFTAR PUSTAKA}

Ekawati, Wayan, 2012, Jejaring Sosial/Facebook sebagai media E-Pengecer (Studi Kasus Mahasiswa di kota Denpasar), Buletin Studi Ekonomi Vol. 17, No,2.

Handayani, Muri, 2016, Emak-Emak Jago Jualan, Bandung: Billionaire Sinergi Korpora. http://smkmuh2-yog.sch.id/v2/, diakses pada 9 April 2018.

Muttaqin, Zainal, 2011, Facebook Marketing Dalam Komunikasi Pemasaran Modern, Teknologi, Vol. 1, No. 2, 103.

Ramsaran, Rooma, 2013, The Implications of Facebook Marketing for Organization, Contemporary Management Research Vol. 9 No. 1.

Tama, Rineka, 2015, Praktik Pengalaman Lapangan (PPL) SMK Muhammadiyah 2 Yogyakarta, Universitas Negeri Yogyakarta.

Utami, Agustin dan Purnama, B, 2012, Pemanfaatan Jejaring Sosial (Facebook) Sebagai Media Bisnis Online (Studi Kasus Di Batik Solo 85), Seruni FTI UNSA, Volume 1. 